\title{
DETERMINING THE FACTORS AFFECTING RANGELAND SUITABILITY FOR LIVESTOCK AND WILDLIFE GRAZING
}

\author{
FARAZMAND, A. ${ }^{1}$ - ARZANI, H. ${ }^{2 *}-$ JAVADI, S. A. ${ }^{1}-$ SANADGOL, A. A. ${ }^{3}$ \\ ${ }^{I}$ Department of Range Management, Science and Research Branch, Islamic Azad University \\ Tehran, Iran \\ (e-mail: alifarazmand53@yahoo.com; phone: +98-912-271-8331; fax: +98-212-244-6515) \\ ${ }^{2}$ Department of Reclamation of Arid and Mountainous Regions, Faculty of Natural Resources, \\ University of Tehran, Karaj, Iran \\ ${ }^{3}$ Rangeland Research Division, Research Institute of Forests and Rangelands, Tehran, Iran \\ *Corresponding author \\ e-mail: harzani@ut.ac.ir, phone: +98-263-222-3044; fax: +98-263-222-7765
}

(Received $7^{\text {th }}$ Jul 2018; accepted $2^{\text {nd }}$ Nov 2018)

\begin{abstract}
Rangelands have a significant role in the supply of forage for grazing livestock and wildlife. Therefore, it is necessary to evaluate the rangeland grazing suitability for livestock and wildlife. In this study, the Jeliz Jand Basin was selected. This basin, with an area of 16210.44 ha, lies between longitudes $52^{\circ} 36^{\prime}$ to $50^{\circ} 52^{\prime} \mathrm{E}$ and latitudes $35^{\circ} 44^{\prime}$ to $35^{\circ} 57^{\prime} \mathrm{N}$. It is located in north of Firouzkooh city, Tehran Province, Iran, and has a cold semi-arid climate. Data integration was carried out according to the FAO method (1991) using GIS on a scale of 1: 20000. For livestock and wildlife grazing, information on physical factors and vegetation in the form of three sub-models including forage production, water resources and soil sensitivity to erosion was integrated and the final model of rangeland suitability was produced. According to the results, the range suitability for sheep and goats grazing in the study area was determined to be moderate (S2) for $11.3 \%$ (1560.3 ha), low (S3) for $80.5 \%$ (11148 ha) and unsuitable (N) for $8.3 \%$ (1146.5 ha), respectively. Rangeland suitability for cattle grazing in the study area was determined to be high (S1) for 1.7\% (228.9 ha), moderate (S2) for 3.6\% (498.6\%), low (S3) for $0.8 \%$ (111 ha) and unsuitable $(\mathrm{N})$ for cattle grazing was $93.9 \%$ (13016.9 ha), respectively. Also, about 1491 ha of rangelands were low suitable for wildlife grazing. It is worth mentioning that slope percentage, vegetation composition (presence of class II and III species) and low vegetation cover because of overgrazing and the past land-use conversions were the most important factors limiting rangeland suitability in this Basin. However, it is necessary to reduce the population of cattle and goat, and grazing program should be set up and continued with sheep according to the principles of range management.
\end{abstract}

Keywords: rangeland analysis, livestock grazing, multiple use, rangeland suitability, wildlife, GIS, Firoozkooh

\section{Introduction}

Livestock grazing is the major exploitation of rangelands in most developing countries, while rangelands, in addition to livestock production, have other benefits including production of medicinal, industrial, and edible plants, production of nectar and pollen plants, creation of tourism and ecotourism areas, soil conservation, wildlife, hunting, water storage and production, carbon sequestration and so forth that could be resulted in improved income for beneficiaries in the form of multipurpose use (Arzani et al., 2009). These benefits have been emphasized in recent decades to commercialize and economize the exploitation units (Arzani et al., 2016). Because of the high energy expended, livestock grazing on high slopes not only decreases the livestock performance but also increases the risk of erosion and flooding. Livestock grazing in 
areas that are susceptible to erosion causes soil degradation and vegetation as well as increased surface area of critical regions. Providing a suitable management plan for rangelands requires identification of its constraints and potential for various types of exploitation. According to FAO (1991), rangeland suitability is defined as the land capability for rangeland exploitation with regard to sustainable land use. Amiri (2008) studied the rangeland suitability of Ghara Aghach rangelands in Esfahan province for livestock grazing and concluded that palatability, species composition and production were the factors limiting grazing suitability in the study area. According to Arzani et al. (2005), steep slope, conversion of rangelands to drylands, early grazing, the rocks susceptible to erosion and low vegetation cover were the most limiting factors in determining rangeland suitability. Toxic plants also reduce rangeland suitability for livestock grazing. Omidvar and Mohtashamnia (2015) also found that among physical and vegetative factors, physical factors such as slope, altitude, distribution of water resources, and precipitation type were more effective in reducing the rangeland suitability as compared with vegetation. According to Arnold and Rodzinsky (1978), this distance depends on vegetation, topography, grazing season, and age of livestock. Gavili et al. (2013) showed that the lack of available forage for livestock due to the low production of desired species as well as low palatability and allowable use were the most important factors in reducing the rangeland suitability of Fereydon Shahr Rangelands of Esfahan. Javadi et al. (2010) considered three sub-models of water resources, soil sensitivity to erosion, and forage production to classify rangeland suitability for goat grazing. According to the results, the rangeland suitability for goat grazing was determined to be S3 for $72.1 \%$ and $\mathrm{N}$ for $27.9 \%$ of the study area, respectively. in Low forage production and the sensitivity of formations to erosion were the most important factors reducing rangeland suitability. Low production and erosion together were identified as limiting factors. In a study conducted by Arzani et al. (2005), physical characteristics and vegetation were introduced as the factors affecting rangeland suitability in Taleghan. Steep slope, conversion of rangelands to drylands, early grazing, the rocks susceptible to erosion, and low vegetation cover were the most limiting factors in determining rangeland suitability. Arzani et al. (2006) studied the range suitability of semi-steppe rangelands in Sabz Kouh, Chahar Mahal Bakhtiari province, and showed the slope was introduced as the main factor in reducing rangeland suitability for livestock grazing. In a study conducted by Mirakhorlou (2000), range condition, trend and capacity were calculated using satellite data, field observations and GIS in Damavand rangelands, and rangeland suitability map was determined for various range improvement methods. Rezaei et al. (2004) investigated soil quality index to assess rangeland suitability for open grazing in Lar Basin. According to Arzani et al. (2006), low forage production, abundant toxic and thorny species around the village and water resources, topography, steep slopes, formations susceptible to erosion, and early cold were among the factors limiting rangeland suitability in Siahrood rangelands, Northeast Tehran. Overall, the factors affecting rangeland suitability are divided into two groups as physical characteristics (slope, the length of range, natural obstacles, sensitivity to erosion, soil stability, water resources, climate, soil properties) and vegetation (production, range condition and trend, capacity, soil cover, and vegetation cover percentage). The present study was aimed to identify the most important factors affecting and limiting rangeland suitability to classify the rangelands of the study area for livestock (sheep, goat, and cattle) and wildlife grazing. Sour et al. (2013) showed the capability of GIS multi criteria evaluation for rangelands suitability assessment. Keno 
Terfa and Suryabhagavan (2015) used Landsat TM 2011 remote sensing satellite images for land-use/land-cover analysis and Multi Criteria Evaluation in a GIS environment to come up with the final suitability map. Ariapour et al. (2013) concluded that using RS and GIS could be useful to water resources suitability of rangeland ecosystems with low cost and high accuracy and speed, if consider standards and criteria of using GIS and RS. According to Rouhi-Moghaddam et al. (2016), in theire study area the limiting factors for sheep grazing had been water resources, high slope and vegetation. Rostami et al. (2014) stated that using GIS may lead to the increase in accuracy and speed of implementing plans.

\section{Materials and methods}

The Jeliz Jand Basin with an area of 16210.44 ha, lies between longitudes $52^{\circ} 36^{\prime}$ to $50^{\circ} 52^{\prime} \mathrm{E}$ and latitudes $35^{\circ} 44^{\prime}$ to $35^{\circ} 57 \mathrm{~N}$. It is located in north of Firouzkooh city, Tehran Province, Iran (Fig. 1). This region has a cold semi-arid climate (modified DeMarton classification). The average annual precipitation is $451.1 \mathrm{~mm}$, and the average annual temperature is 3.1. The current land use in the study area includes range management, dry agriculture, irrigated agriculture, gardens, residential areas, planted forests, and bare lands. Rangelands cover $85.5 \%$ of the study area.

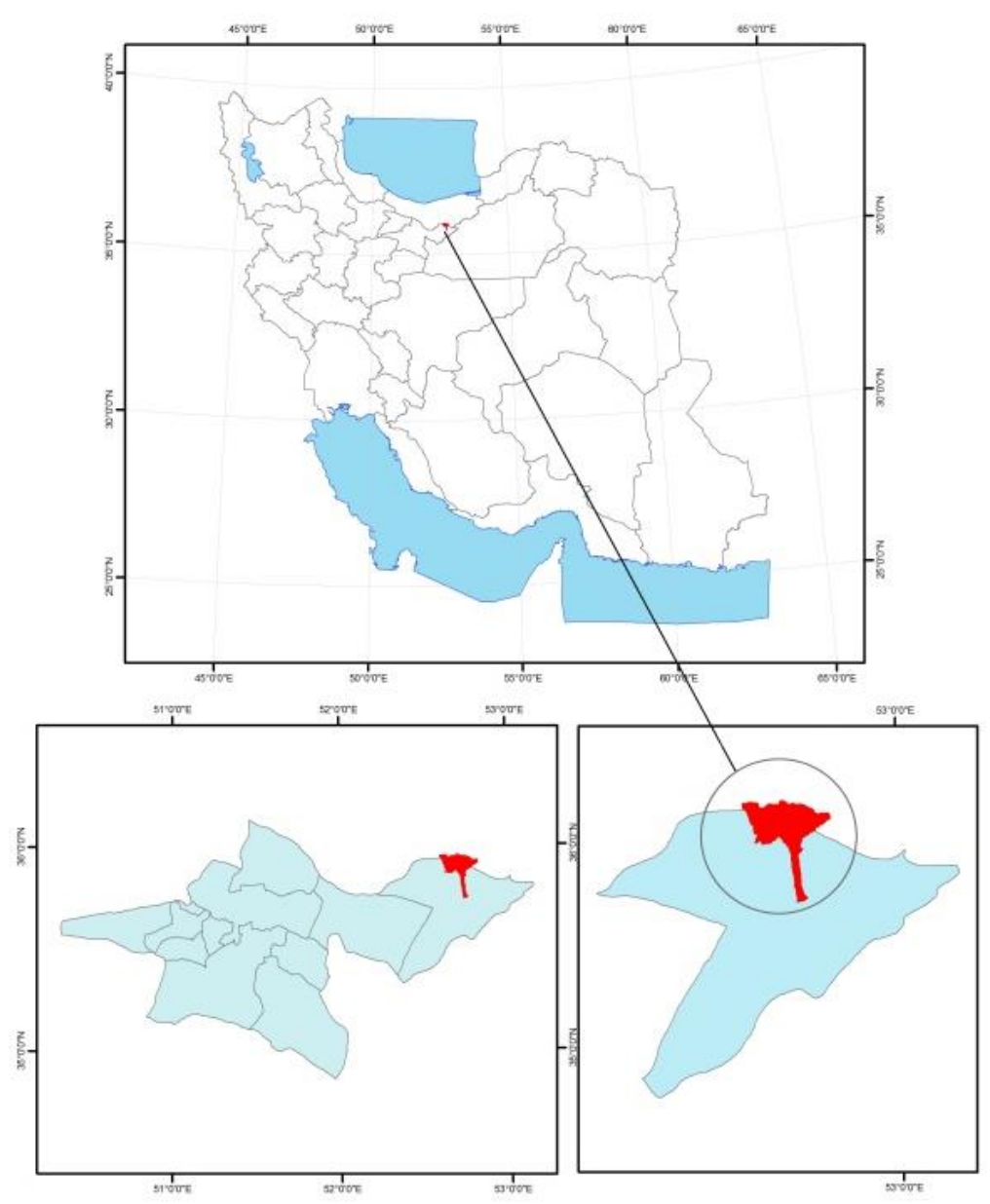

Figure 1. Geographical location of Jeliz Jand in Tehran and Iran 
Data integration was carried out according to the FAO method (1991) using GIS on a scale of 1: 20000. Four suitability classes were determined as high (S1), moderate (S2), low (S3), and unsuitable (N). The software MapSource 6.11.6 and ArcGIS 10 were used in this research.

\section{Suitability for livestock (sheep, goat, and cattle) and wildlife grazing}

First, the current condition of rangelands was studied. In order to update vegetation data, a vegetation map was developed (Fig. 2a). Rangeland types were identified using field observations and GPS. The range condition and range trend were determined using the four-factor method and trend scale method, respectively. Figure $2 b$ shows the range allotment map. Forage production was determined by cutting and weighing method. In addition, rangeland capacity, palatability, allowable use, forage quality, livestock type and daily requirement, grazing season, and rangeland area were determined. To determine rangeland suitability for livestock (sheep, goat, cattle) and wildlife grazing, first, three sub-models of soil sensitivity to erosion, water resources and forage production were prepared and finally, these three sub-models were integrated and the final map of rangeland suitability was obtained.

\section{Soil sensitivity to erosion}

Soil sensitivity to erosion was determined by MPSIAC method. In this method, nine factors including geology, soil texture, climate, runoff, topography, vegetation, land use, current erosion, and gully erosion were evaluated (Table 1).

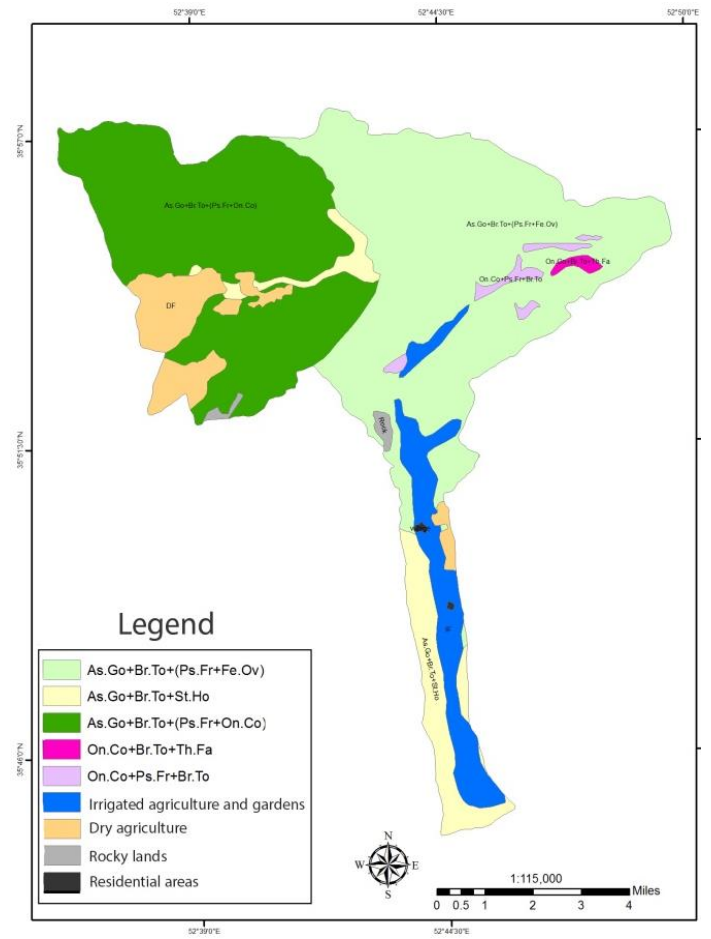

$\mathbf{a}$

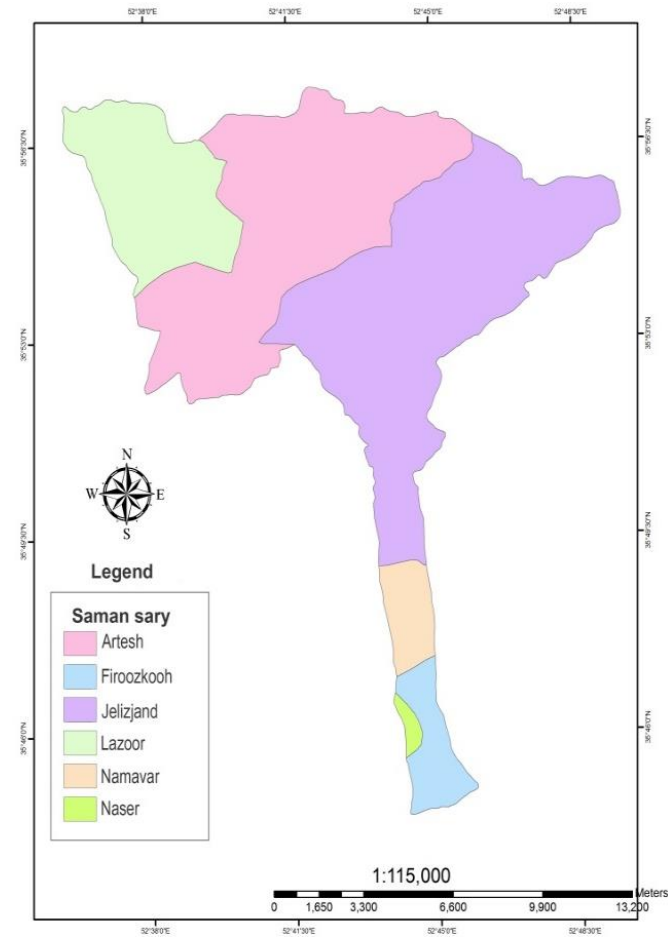

b

Figure 2. a. Vegetation types map. (The abbreviations indicate the vegetation types of the study area, presented in detail in Table 8). $\boldsymbol{b}$. Range allotment map 
Table 1. The area of erosion classes for rangeland suitability classes

\begin{tabular}{c|c|c|c|c}
\hline Erosion class & I & II & III & IV \\
\hline Area/h & $939 / 6$ & $5043 / 5$ & $7872 / 3$ & 0 \\
\hline Suitability class & S1 & S2 & S3 & N \\
\hline$\%$ & $6 / 78$ & $36 / 4$ & $56 / 8$ & 0 \\
\hline
\end{tabular}

\section{Water resources sub-model}

The sub-model of water resources includes the slope (Table 2), distance from water resources (Table 3), water quantity, and water quality. Generally, the ability to access water resources depends on maximum distance that livestock can be moved from water resource for grazing.

Table 2. Slope suitability classes for livestock and wildlife

\begin{tabular}{c|c|c|c|c}
\hline Slope (\%) & $0-10$ & $11-30$ & $31-70$ & $>70$ \\
\hline Sheep and goat & S1 & S2 & S3 & N \\
\hline Cattle & S1 & S2 & N & N \\
\hline Wildlife & N & N & S1 & S2 \\
\hline
\end{tabular}

Table 3. Suitability classes for distance from water resources

\begin{tabular}{c|c|c|c|c}
\hline Suitability Class & S1 & S2 & S3 & N \\
\hline Distance/km & $0-2$ & $2-4$ & $4-6$ & $6-8$ \\
\hline
\end{tabular}

Considering the climatic factors, vegetation characteristics, exploitation season, livestock type, livestock breed, and species composition, the daily water requirement of animal unit in the study area based on forage composition available to animals was considered as 5 liters. Then, the quantity of water was determined in each watering point. The water quantity was determined through comparison of the amount of water available and the amount of water required for livestock (Table 4). The water quality sub model was determined using the factors affecting the quality of drinking water for sheep and its comparison with the water quality in the study area (Tables 5 and 6). Finally, the maps derived from the sub-models were integrated using the limiting factor procedure suggested by (FAO, 1991) and the sub model of water was prepared.

Table 4. Water quantity guide for livestock and wildlife

\begin{tabular}{c|c|c|c|c}
\hline $\begin{array}{c}\text { Available water in the rangeland } \\
\text { relative to the livestock requirement(\%) }\end{array}$ & $25<$ & $25-50$ & $50-75$ & $75>$ \\
\hline Sheep and goat & $\mathrm{N}$ & $\mathrm{S} 3$ & $\mathrm{~S} 2$ & $\mathrm{~S} 1$ \\
\hline Cattle & $\mathrm{N}$ & $\mathrm{S} 3$ & $\mathrm{~S} 2$ & $\mathrm{~S} 1$ \\
\hline Wildlife & $\mathrm{N}$ & $\mathrm{S} 3$ & $\mathrm{~S} 2$ & $\mathrm{~S} 1$ \\
\hline
\end{tabular}


Table 5. Factors affecting the quality of drinking water (Mahdavi, 2003)

\begin{tabular}{c|c}
\hline Factor & Maximum resistance for sheep and goats \\
\hline $\mathrm{EC}(\mathrm{mmhos} / \mathrm{cm})$ & 16 \\
$\mathrm{Mg}(\mathrm{mg} / \mathrm{lit})$ & 500 \\
$\mathrm{TDS}(\mathrm{mg} / \mathrm{lit})$ & 12900 \\
\hline
\end{tabular}

Table 6. Total water soluble solids (ppm)

\begin{tabular}{c|c|c|c|c}
\hline Animal type & Good & Fair & Poor & Limitation \\
\hline Sheep & $1000<$ & $3000-6000$ & $6000-10000$ & $10000>$ \\
goat & $1000<$ & $5000-7000$ & $7000-10000$ & $10000>$ \\
Cattle & $1000<$ & $5000-7000$ & $7000-10000$ & $10000>$ \\
Wildlife & $1000<$ & $3000-6000$ & $6000-10000$ & $10000>$ \\
\hline
\end{tabular}

\section{Forage production and grazing capacity sub model}

In order to determine the forage production and the grazing capacity in the vegetation types, firstly, the rate of production of species was harvested by clipping and weighing method in each plot at the end of the vegetative growth stage. Then, the available production in vegetation types for livestock (sheep, goat, and cattle) was calculated by combining the production data with palatability or proper use factor. In order to determine the suitability class of forage production, the ratio of the amount of available production of each vegetation type to its total production was used (Table 7). Due to determination of water quantity need for livestock grazing, also, rangeland grazing capacity was calculated for each vegetation type using the amount of forage used for livestock, length of grazing period (105 days), daily animal unit requirement $(1.3 \mathrm{~kg})$ and rangeland area.

Table 7. Guidelines for forage production suitability classes by FAO Method (1991)

\begin{tabular}{c|c|c}
\hline Row & Available production to total production ratio (\%) & Production suitability \\
\hline 1 & $20>$ & $\mathrm{S} 1$ \\
2 & $15-20$ & $\mathrm{~S} 2$ \\
3 & $10-15$ & $\mathrm{~S} 3$ \\
4 & $10<$ & $\mathrm{N}$ \\
\hline
\end{tabular}

\section{Rangeland suitability for wildlife}

Rangelands with slopes greater than $70 \%$ and rangelands susceptible to erosion, known as protected areas, are recommended for wild goat, goat, ewe, and ram grazing. First, the map of the slopes greater than $70 \%$ was prepared with a scale of 1:25000. The map of high and very high susceptibility to erosion was provided using the erosion classes' map. By integrating the maps of susceptibility to erosion, water resources, forage production and slope, the rangeland conservation map was produced, whose land use was wildlife grazing. 


\section{Results}

According to the results, rangelands comprise 13,855 ha of the study basin, whose slope is below $70 \%$ for 12364 ha and above $70 \%$ for 1491 ha. The vegetation cover consists of 76 plant species belonging to 21 plant families and five vegetation types. The amount of forage production that could be harvested is 2666.5 tons per year (Table 8).

Table 8. Characteristics of rangeland types on the Jeliz Jand Basin, Firouzkooh

\begin{tabular}{|c|c|c|c|c|c|c|c|}
\hline Row & Rangeland types & $\begin{array}{c}\text { Area } \\
\text { (ha) }\end{array}$ & Condition & Trend & $\begin{array}{c}\text { Available } \\
\text { forage } \\
\mathrm{kg} / \mathrm{ha}\end{array}$ & $\begin{array}{l}\text { Capacity } \\
(\text { a.u.m/h) }\end{array}$ & $\begin{array}{c}\text { Grazing } \\
\text { capacity } \\
\text { (animal } \\
\text { unit) }\end{array}$ \\
\hline 1 & $\begin{array}{c}\text { Astragalus gossypinus + Bromus } \\
\text { tomentellus + Stipa hohenckeriana }\end{array}$ & 1176 & Poor & $(-)$ & $171 / 4$ & 4977 & - \\
\hline 2 & $\begin{array}{l}\text { Astragalus gossypinus }+ \text { Bromus } \\
\text { tomentellus }+ \text { Psathyrostachys fragilis } \\
+ \text { Festuca }\end{array}$ & 6155 & Fair & $(-)$ & $208 / 2$ & 32827 & 9379 \\
\hline 3 & $\begin{array}{l}\text { Astragalus gossypinus }+ \text { Bromus } \\
\text { tomentellus }+ \text { (Psathyrostachys fragilis } \\
+ \text { Onobrychis cornuta) }\end{array}$ & 4832 & Good & 0 & 236 & 29239 & 8354 \\
\hline 4 & $\begin{array}{c}\text { Onobrychis cornuta + Bromus } \\
\text { tomentellus }+ \text { Thymus fallax Fisch. }\end{array}$ & 57 & Fair & $(-)$ & $198 / 2$ & 278 & 79 \\
\hline 5 & $\begin{array}{l}\text { Onobrychis cornuta }+ \text { Psathyrostachys } \\
\text { fragilis }+ \text { Bromus tomentellus }\end{array}$ & 179 & Fair & $(-)$ & 187 & 826 & 236 \\
\hline Total & - & 12364 & - & - & - & - & 18048 \\
\hline
\end{tabular}

Soil susceptibility to erosion sub model: According to the results, the rangeland suitability was determined to be good for $6.78 \%$ (939.6.6 ha), moderate for $36.4 \%$ (5043.5 ha), and fair for 56.8\% (7872.3 ha) of rangelands. Water resources sub-model: An area of 10498 ha of rangelands with a slope below $70 \%$ was suitable for sheep and goat common grazing, 600 ha for cattle grazing and 400 ha for wildlife grazing. All rangelands with a slope of over $70 \%$ (1491 ha) can only be attributed to wildlife grazing (Table 9). The daily water requirement of a livestock unit weighing $50 \mathrm{~g}$ is about 51 depending on the region, and the water requirement of each livestock unit is equal to 4321 during the grazing season. Water requirement for livestock and wildlife in the area is $9000.4 \mathrm{~m}^{3}$ and the available water is $6070000 \mathrm{~m}^{3}$; therefore, the suitability of the entire area was determined to be $\mathrm{S} 1$. There is no limitation in terms of water quality (sheep, goat, cattle, and wildlife) in the study area (S1 class). In terms of water resources distance (sheep, goat, cattle, and wildlife), the suitability of rangelands was determined to be S1 for 12718 ha and S2 for 1137 ha. Rangeland suitability for water resources was determined to be S1 for $3.3 \%$ of the study area (461.2 ha), S2 for $26.4 \%$ (3652 ha), S3 for 62\% (8594.5 ha), and $\mathrm{N}$ for $8.3 \%$ (1146.5 ha).

Table 9. Slope suitability classes for livestock and wildlife

\begin{tabular}{c|c|c|c|c}
\hline Slope (\%) & $0-10$ & $11-30$ & $31-70$ & $70>$ \\
\hline Area/ha & 2778 & 4847 & $5 / 3873$ & $1491 / 3$ \\
\hline Sheep and goat/ha & 2478 & 4547 & $5 / 3473$ & 0 \\
\hline Cattle/ha & 300 & 300 & 0 & 0 \\
\hline Wildlife/ha & 0 & 0 & 400 & $1491 / 3$ \\
\hline
\end{tabular}




\section{Forage production sub-model:}

Available forage production and grazing capacity for livestock and wildlife are presented in (Table 10). Rangeland suitability for forage production was determined to be S2 for 6244 ha (50.36) and S3 for 6154.85 ha (49.64).

Table 10. A comparison of available forage production and grazing capacity between livestock and wildlife

\begin{tabular}{c|c|c|c|c}
\hline Row & Method parameter & Area (ha) & Available forage (kg) & $\begin{array}{c}\text { Grazing capacity } \\
\text { (animal unit) }\end{array}$ \\
\hline A & Livestock & $12398 / 35$ & $2666697 / 4$ & 18047 \\
\hline B & Wildlife & $1491 / 3$ & $224467 / 3$ & $1845 / 2$ \\
\hline C & $\begin{array}{c}\text { On slopes that are not suitable for } \\
\text { livestock grazing }\end{array}$ & - & - & - \\
\hline
\end{tabular}

Final model of rangeland suitability for grazing: the model was obtained from integration of layers including soil susceptibility to erosion, water and forage. According to the results, rangeland suitability for sheep and goat grazing was determined to be S2 for $11.3 \%$ (1560.3 ha), S3 for 80.5\% (11148 ha), and $\mathrm{N}$ for $8.3 \%$ (1146.5 ha) (Fig. 3a). Rangeland suitability for cattle grazing was determined to be S1 for $1.7 \%$ (228.9 ha), S2 for 3.6\% (498.6 ha), S3 for 0.8\% (111 ha), and N for $93.9 \%$ (13016.9 ha) (Fig. 3b). The suitability of the rangelands for wildlife grazing, where the slope was greater than $70 \%$ with an area of 1491 ha, was determined to be S3 (Fig. 3c). The map of common grazing by livestock and wildlife is presented in Fig. $3 d$.

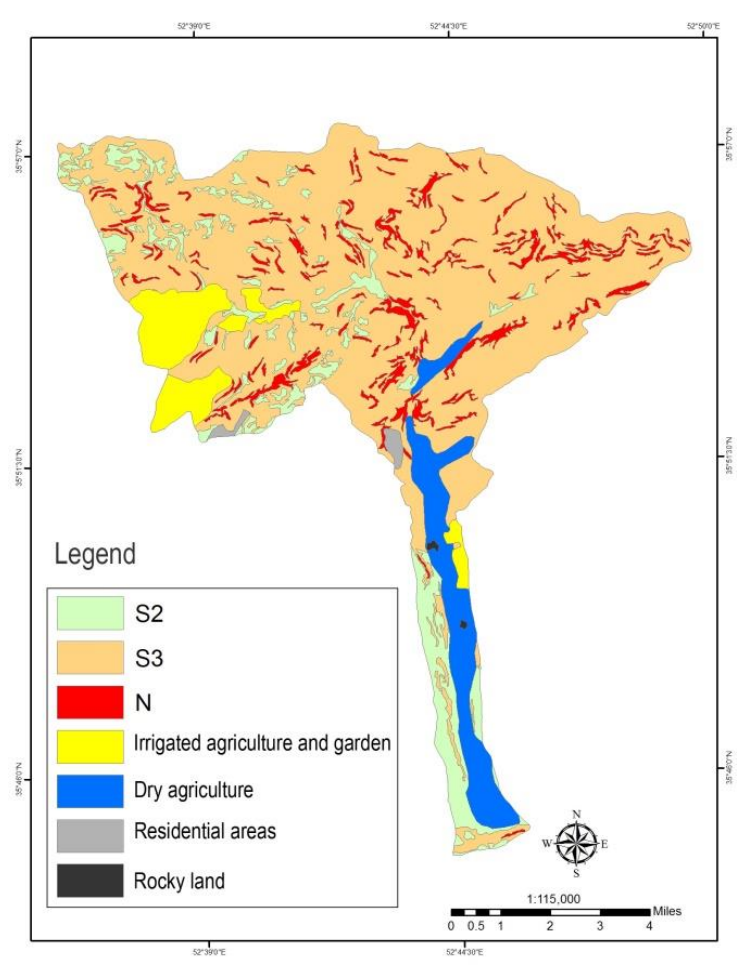

$\mathbf{a}$

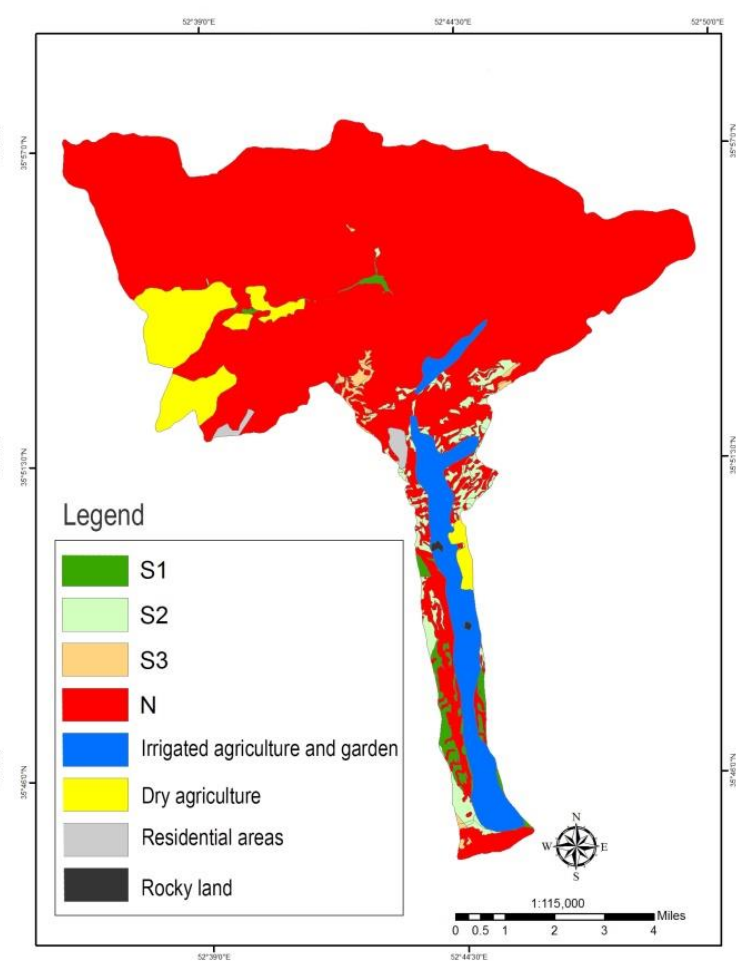

$\mathbf{b}$ 

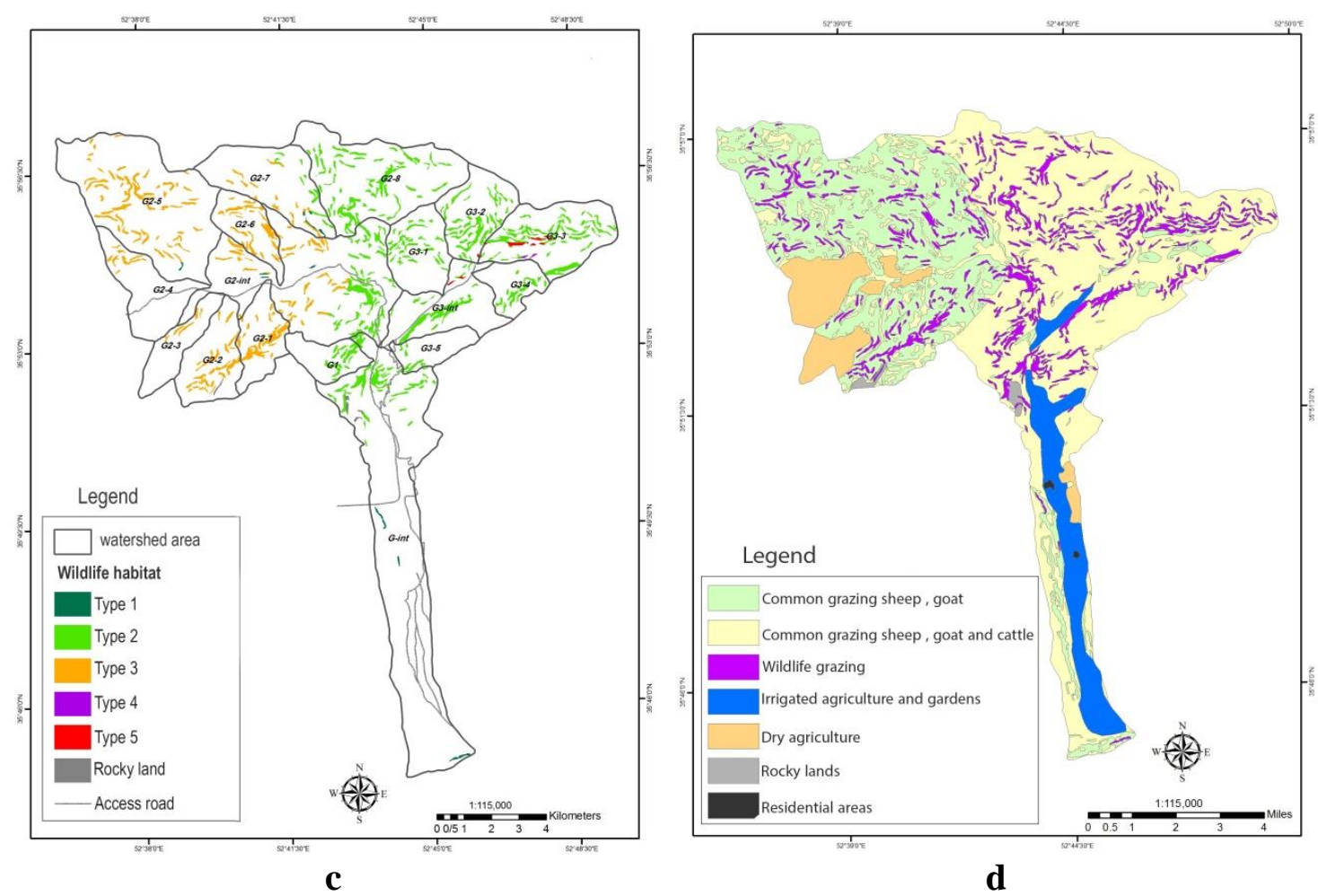

Figure 3. a. Rangeland suitability map for sheep and goat grazing, $\boldsymbol{b}$. cattle grazing, $\boldsymbol{c}$. wildlife grazing and $\boldsymbol{d}$. livestock and wildlife common grazing

According to the results, the suitability of the study rangelands for common grazing by livestock and wildlife was determined as follows:

A: 12377 ha of rangelands, where the slope is less than $70 \%$, can be used for common grazing by sheep and goat.

B: 7624 ha of rangelands, where the slope is less than $30 \%$, can be used for common grazing by sheep, goat and cattle.

C: 1491 ha of the study rangelands, where the slope is greater than $70 \%$, can only be grazed by wildlife (Fig. 3d).

\section{Discussion}

Knowledge of forage production, water resources, and soil sensitivity to erosion is essential to determine rangeland suitability. Palatability, proper use factor are effective for detrmining, available forage to animals, Amount of production is another factor considered for the production factor. Distance and access to water as well as water quality and quantity are considered for the water resources assessment. The erosion model or rock and soil sensitivity to erosion also include nine factors (geology, climate, soil, runoff, topography, land use, land cover, surface erosion, and river erosion). According to Javadi et al. (2009, 2008, 2006), Arzani et al. (2009, 2017), Alizadeh et al. (2013), Sanaei et al. (2015) and Motamedi and Toopchzadegan (2017), three factors including forage production, water resources and soil susceptibility to erosion were the components of the livestock grazing model. The suitability of most of the lands in the study area was determined to be low (S3) and moderate (S2) for soil susceptibility to 
erosion. In a study performed by Alizadeh et al. (2011) in Ghara Aghach, land use, surface cover, runoff and current erosions were respectively introduced as the most important factors affecting the erosion of this basin. The land use type was the most important factor in reducing the rangeland suitability in Roozeh Chai, Urmia (Bani Nemeh, 2003). The negative impacts of overgrazing and early grazing on reduced permeability and increased run off have been reported in several studies (Arzani et al., 2005). In terms of water resources (quantity, quality, and distance from water resources), the suitability of rangeland for most of the lands in the study area was determined to be low and moderate. In the study area, regarding the climatic conditions, the quantity (number of permanent water resources), quality, and distance from water resources, were not limited factors for animal grazing, and all rangeland types were placed in the S1 suitability class. To explain the importance of slope in access to water resources he stated that animals' ability for grazing is reduced by increasing of slope and more energy is consumed. However, the quality and quantity of water resources in the study area caused no limitation. Alizadeh et al. (2011) stated that slope was the most important factor in reducing rangeland suitability in terms of distance from water resources in Semirom region. This result is consistent with our findings in the present study. Gavili et al. (2010) also considered slope as the factor reducing and sometimes limiting rangeland suitability. Therefore, slope has a significant importance in determining rangeland suitability for livestock grazing, so that water penetration is reduced by increasing of slope, resulting in increased run off. On the other hand, the establishment possibility of developed soils decreases on steep slopes and livestock (animal) grazing on steep slopes causes soil movement and difficult plant establishment. In addition, animals spend a lot of energy to move on the steep slopes (for grazing and to reach water sources). Therefore, animal performance is reduced. According to Holchek et al. (2001) and Zhou (1989), the steep slopes (greater than 60\% or 75\%) are inappropriate for animal grazing. They point out that wildlife graze better than do livestock on steep slopes. In the case of steep slopes, no grazing is recommended and the area should be considered for wildlife and tourism only. The suitability class of most of the rangeland vegetation types was determined to be $\mathrm{S} 2$ and $\mathrm{S} 3$ for forage production. In the present study, the presence of class II and class III species in the species composition and reduced available forage were the most important factors in reducing the range suitability of the study basin for forage production. All rangelands used by wildlife, with an area of 1491 ha, were classified in the S3 suitability class for forage production. The impact of past uses (conversion of rangelands to dry farming and overgrazing), low vegetation cover, and presence of low-palatability species in the vegetation composition were among the factors reducing rangeland suitability for forage production. Rangeland plowing, in order to develop dry-land cultivation in areas where the annual rainfall provides dryland farming, is one of the factors of rangeland degradation. Such rangelands, having good and deep soil, are among the best rangelands. Grasses and annual forbs produce temporary cover (during the period of the growing season). Therefore, at most times of the year, the soil surface is free of vegetation and exposed to erosion. According to Arzani et al. (2005), rangeland conversion to dry land farming, overgrazing, early grazing, low vegetation cover, and the presence of low palatable species were among the most important factors, limiting rangeland suitability for forage production. Motamedi and Toopchzadegan (2017) stated that in the Hendovan rangelands of Khoy the allowable use, available forage, quantity of water resources, and geology were the most important factors. Accordingly, more 
attention need to be paid on designing the guidelines of rangeland suitability for animal grazing and assessing its capability as well as determining the priority of using the vegetation types with the same suitability class. In a study performed by Kit (2000), rangeland suitability was studied in Australia and slope and water resources were identified as the factors limiting rangeland suitability for cattle grazing. In the Qara Aghach rangelands, water resources do not cause limitation on rangeland suitability due to the numerous permanent water resources, while slope is the only factor limiting rangeland suitability in a limited area of the study region. Mfitumukiza (2004) studied the rangeland suitability for cattle grazing in $\mathrm{Ga}$ za province, Mozambique, and concluded that among the factors limiting rangeland suitability, the lack of access to water resources, low palatability of species, low forage production, and slope were the most important factors. The results of a study performed by Mostafaei (2015) in the winter rangelands of Hormozgan showed that the suitability of the study rangelands was determined to be unsuitable (N) or low (S3). According to a study performed by Arzani et al. (2006) in the Siahrood region, toxic plants, high slope, temporary water resources and erosion-sensitive formations were the factors limiting rangeland suitability for sheep grazing. High slope and rock and soil sensitivity to erosion were the factors limiting the suitability of rangelands in the Lar area, in order of importance. In the Ardestan area, low production, invasive plants, distance from water resources, exploitation type, and current erosion result in reduced suitability rangeland. In the Bacan plain, slope, distribution of water resources, and the lack of permanent water resources were the factors limiting the suitability of rangelands for sheep grazing. As can be seen, most studies on grazing in rangelands in different climatic regions of the country are consistent with the results of this study. More than $80 \%$ of the rangelands of the study area have a low suitability (S3) for sheep grazing. In addition, the rangeland suitability for wildlife grazing was determined to be low (S3). In presenting the grazing suitability model, it should be noted that the factors affecting rangeland suitability will be different due to climatic conditions, vegetation, soil, current exploitation conditions, and topography. Given that the rangelands of the region are currently grazed by sheep, goats, and cattle, it is recommended that sheep grazing could be continued based on grazing program and range management principles. However, the number of cattle and goats should be reduced.

\section{Conclusion}

Our results clearly showed that multiple use of rangelands could increase the beneficiaries' income and rangeland sustainable development. However, for future studies, it is necessary to udtae the methods and socio-economic issues need be taken into consideration.

\section{REFERENCES}

[1] Alizadeh, E., Arzani, H., Azarnivand, H., Mohajeri, A., Kaboli, H. (2011): Range suitability classification for goats using GIS Case Study: Ghareaghach watershedSemirom. - Iranian journal of Range and Desert Reseach 18(3): 353-371.

[2] Amiri, F., Arzani, H., Farah Pour, M., Chai Chi, S., Khajedin, S. J. (2008): Multiple use modal of lands with using GIS (Case study: Ghara aghach basin). - PhD Thesis, Azad Islamic University, Research \& Science Unit (in Persian). 
[3] Ariapour, A., Hadidi, M., Karami, K., Amiri, F. (2016): Water resources suitability model by using GIS (case study: Borujerd Rangeland, Sarab Sefid). - Journal of Rangeland Science 3(2): 177-188.

[4] Arnold, G. W., Dudzinsky, M. L. (1978): Ethology of Free Ranging Domestic Animals. -Elsevier Scientific Co., Amsterdam, New York.

[5] Arzani, H. (2009): Forage Quality and Daily Requirement of Grazing Animal. University of Tehran Press, Tehran.

[6] Arzani, H., Yousefi, S., Jafari, M., Farahpour, M. (2004): Rangeland classification model for sheep grazing using GIS. - Journal of Environmental Studies 37: 59-68.

[7] Arzani, H., Farzam, M., Shams, H., Mohtashamnia, S., Mohseni Fashami, M., Ahmadi, H., Jafari, M., Darvish Sefat, A. A., Shahriari, E. (2005): Rangeland classification model for sheep grazing in the central Alborz, Ardestan and Zagros. - Journal of Sciences and Technology of Agriculture and Natural Resources 35: 273.

[8] Arzani, H., Jankjo, M., Shams, H., Mohtashamnia, S., Fashami, M. A., Ahmadi, H., Jafari, M., Darvishsefat, A. A., Shahriary, E. (2006): A model for classification of range suitability for sheep grazing in Central Alborz, Ardestan and Zagros regions. - Iranian Journal of Science and Technology of Agriculture and Natural Resources 10: 273290.

[9] Arzani, H., Naseri, K. (2007): Livestock Feeding on Pasture (translated). - University of Tehran Press, Tehran.

[10] Arzani, H., Mousavi, S. A., Ajdari, G. (2008): Classification of Taleghan Rangeland for Multi Purpose Use and Sustainable Management Report. - Univ. of Tehran, Tehran.

[11] Arzani, H., Borhani, M., Charesaz, N. (2016): Global Rangelands, Progress and Prospects (translated). - Puneh Press, Tehran.

[12] Arzani, H., Beiniaz, M., Alizadeh, E. (2017): Model of Extensive Cattle Grazing for Sustainable Use in Rangelands. - International Conference on Sustainable Development, Canada, Ottawa.

[13] Bani Nameh, J. (2003): Land evaluation for land use planning with special attention to sustainable fodder production in the Rouzeh chahi catchments of Orumiyeh area Iran. M.Sc. Thesis International for Geo-information Science and Earth Observation, Enschede, Netherlands.

[14] Curran, G, Grice, T. (1992): Poisoning Caused by Plants - In: Simpson, I. (ed.) Rangeland Management in Western New South Wales. NSW Agriculture, Sydney, pp. 102-113.

[15] Fashtami, M. (2002): Investigation on range suitability of Lar rangelands using GIS. MScThesis, Tarbiat Modares University.

[16] FAO (1991): Guidelines: Land Evaluation for Extensive Grazing. - Soil Bulletin No. 58. FAO, Rome.

[17] Gavili, E., Vahabi, M., Amiri, F., Arzani, H. (2013): Suitability determination for sheep in rangeland of Ferydounshahr, Isfahan. - Journal of Range and Watershed Management 6(4): 595-607.

[18] Holchek, J. L., Pieper, R. D., Herbel, C. H. (2001): Range Management. Principles and Practices. - Prentice Hall, Englewood Cliffs, NJ.

[19] Javadi, S. A., Asadpour, A., Arzani, H. (2009): Classification of rangeland suitability for goat grazing using GIS (Case study: Baft Jamilabad Range). - Renewable Natural Resources Research 1: 13-29.

[20] Jiao, J, Zou, H., Jia, Y, Wang, N. (2009): Research progress on the effects of soil erosion on vegetation. - Acta Ecologica Sinica 29(2): 85-91.

[21] Keno Terfa, B., Suryabhagavan, K. V. (2015): Rangeland suitability evaluation for livestock production using remote sensing and GIS techniques in Dire District, Southern Ethiopia. - Global Journal of Science Frontier Research: H,Environment \& Earth Science 15(1): 11-25.

[22] Kiet, S. (2000): Expected use GIS map. - Rangeland 22(2): 18-20.

[23] Mahdavi, M. (2002): Applied Hydrology. - University of Tehran Press, Tehran. 
[24] Mfitumukiza, D. (2004): Evaluating rangeland potentials for cattle grazing in a mixed farming system. - Master of Science Thesis, Department of Natural Resources, the Netherlands. http://www.itc.nl/librry/papers2004/msc/nrm/mfitumukiza.pdf.

[25] Mir Akhorlou, K. (2000): the use of geographic information systems and remote sensing (GIS, RS) in rangeland management. - Proceedings of Geomatics Conference, Mapping Organization, Tehran, Iran.

[26] Mostafaei, A. (2014): Economization of rangeland utilization with multiple use in line with sustainable development of the site. - International Conference on Agriculture, Environment and Tourism, Tabriz, Iran.

[27] Motamedi, J., Toopchizadegan, S. (2017): Evaluation of rangeland suitability for sheep and goats common grazing. - Journal of Rangeland 11(1): 27-42.

[28] Omidvar, E., Mohtashamnia, S. (2014): Rangelands suitability for sheep grazing in semi-steppic rangelands of Tornas Eghlid Fars Province by GIS. - Renewable Natural Resources Research 6(2): 65-78.

[29] Rezaei, S. A., Gilkes, R. J., Tongway, D., Arzani, H. (2004): The use of soil surface properties in rangeland capability assessment through landscape function analysis. Proc. World Engineers Convention, China.

[30] Rostami, E., Mehrabe, H., Farahpour, M. (2014): Determining rangeland suitability for sheep grazing using GIS (case study: Sadegh Abad Watershed, Kermanshah Province, Iran). - Journal of Rangeland Science 4(4): 319-329.

[31] Rouhi-Moghaddam, E., Joloro, H., Memarian, H. (2017): Determining range suitability using fuzzy and hierarchical method (case study: Bagheran Birjand Watershed, SouthKhorasan Province, Iran). - Journal of Rangeland Science 7(3): 232-241.

[32] Sanaei, A., Arzani, H., Tavili, A., Farahpour, M. (2015): Assessment of range suitability for sheep grazing according to the MSSG instructions (Case study: Central Taleghan). Iranian Journal of Range and Desert Research 22(2): 275-288.

[33] Schilling, K. E., Chan, K. S., Liu, H., Zhang, Y. K. (2010): Quantifying the effect of land use land cover change on increasing discharge in the Upper Mississippi River. Journal of Hydrology 387(3-4): 343-345.

[34] Sour, A., Arzani, H., Feizizadeh, B., Tavili, A., Alizadeh, E. (2013): GIS Multi-Criteria Evolution for Determination of Rangelands Suitability for Goat Grazing in the Middle Taleghan Rangelands. - International Journal of Agronomy and Plant Production 4(7): 1499-1510.

[35] Zhou, Q. (1989): The integration of remote sensing and geographical information systems land resources management in the Australian arid zone. - PhD Thesis, The University of New South Wales Australia. 